\title{
ВИКОРИСТАННЯ СЕРВІСІВ GООGLЕ ПІД ЧАС ВИВЧЕННЯ КУРСУ «ОСВІТНЯ ПОЛІТИКА»
}

\author{
Світлана Процька \\ кандидат педагогічних наук, доцент, \\ доцент кафедри соціальної філософії, філософії освіти та освітньої політики, \\ Національний педагогічний університет імені М.П. Драгоманова, \\ м. Київ, Україна \\ ORCID ID 0000-0002-9212-8700 \\ s.m.protska@npu.edu.ua
}

\begin{abstract}
Анотація. У статті обгрунтовано практичні аспекти використання сервісів Google під час вивчення курсу «Освітня політика» для студентів другого (магістерського) рівня вищої освіти в умовах інформатизації педагогічних закладів вищої освіти; розкрито роль сервісів Google (на прикладі Google Classroom) у процесі формування професійних компетентностей майбутнього магістра освітніх наук, окреслено їх характеристики: економію засобів на придбання програмового забезпечення; зниження потреби в спеціалізованих аудиторіях; можливість виконання багатьох видів діяльності, контролю та оцінки досягнень студентів online; відкритість освітнього середовища; визначено складники професійних компетентностей майбутнього магістра освітніх наук: предметний; інформаційно-цифровий; комунікативний; особистісний; наведено приклади педагогічного використання елементів сервісів Google для формування професійних компетентностей майбутнього магістра освітніх наук у закладах вищої освіти в процесі вивчення навчальної дисципліни (освітнього компонента) «Освітня політика».
\end{abstract}

Ключові слова: магістр освітніх наук; інформатизація освіти; інформаційнокомунікаційні технології; професійні компетентності; сервіс Google Classroom.

Постановка проблеми в загальному вигляді. Формування професійних компетентностей майбутнього фахівця в умовах упровадження сучасних інформаційних технологій у практику освітнього процесу є одним із ключових пріоритетів розвитку педагогічної вищої освіти сучасної України. Так, стратегічно важливим напрямом у системі вищої освіти вважаємо організацію та впровадження сервісів Google в освітнє середовище, які створюють нові можливості для реалізації особистісного потенціалу майбутнього магістра освітніх наук.

На основі аналізу психолого-педагогічної літератури виявлено, що в Україні надається належну увагу дослідженню проблем інформатизації освіти, застосування в освітньому процесі навчальних закладів інформаційнокомунікаційних технологій (IКТ). Проте дослідження проблем застосування сервісів Google для формування професійних компетентностей майбутнього магістра освітніх наук в умовах інформатизації закладів вищої освіти (ЗВО)

() ДВНЗ «Донбаський державний педагогічний університет» 
проводилися фрагментарно, що обгрунтовує актуальність їх здійснення 3 урахуванням сучасних викликів інформаційного суспільства.

Аналіз останніх досліджень і публікацій. Різні аспекти проблеми вдосконалення компетентнісного підходу, використання IКT у процесі професійної підготовки майбутніх учителів висвітлено в наукових працях вітчизняних та зарубіжних науковців, а саме: досліджували теоретичні й практичні аспекти використання ІКТ в освітньому процесі ЗВО - В. Биков, О. Глазунова, О. Глушак, М. Жалдак, О. Жильцов, Ю. Жук, О. Колгатін, К. Колос, М. Лещенко, С. Литвинова, А. Манако, Н. Морзе, Ю. Носенко, О. Овчарук, Л. Пєтухова, О. Пінчук, О. Соколюк, Н. Сороко, О. Співаковський, Є. Співаковська-Ванденберг, О. Спірін, Ю. Триус, М. Шишкіна, А. Яцишин та інші; обгрунтовували теоретико-методологічні й методичні основи застосування компетентнісного підходу в процесі підготовки фахівців із вищою освітою О. Антонова, Н. Бібік, В. Бобрицька, Л. Клос, Л. Кравченко, О. Локшина, О. Овчарук, О. Пометун, О. Савченко, В. Ягупов та інші.

Формулювання цілей статті (постановка завдання). Мета дослідження полягає в обгрунтуванні використання сервісів Google під час вивчення курсу «Освітня політика» для студентів другого (магістерського) рівня вищої освіти в умовах інформатизації педагогічних закладів вищої освіти.

Для досягнення мети визначено такі завдання: розкрити роль сервісів Google (на прикладі Google Classroom) у процесі формування професійних компетентностей майбутнього магістра освітніх наук; навести приклади педагогічного використання елементів сервісів Google для формування професійних компетентностей майбутнього магістра освітніх наук у ЗВО.

Результати дослідження. Узагальнюючи думки вчених на сутнісні характеристики процесу формування інформаційного суспільства, поділяємо їх висновки про те, що IКТ усе більше проникають у різні сфери життя, науки, освіти, виробництва, що вимагає від фахівців відповідних знань та вмінь їх застосовувати (Бобрицька \& Глушак, 2014). Передусім зазначимо, що наша дослідницька позиція суголосна 3 науковою думкою В. Бобрицької, яка відзначає, що одним із чинників, який суттєво впливає на вдосконалення професійної підготовки магістра освітніх наук, $є$ зміст і структура освітнього середовища як засобу формування їх професійних компетентностей (Бобрицька, 2011; Бобрицька, 2015).

Зазначимо, що всі інноваційні зміни, передусім, залежать від самого студента, його творчого потенціалу, креативності, готовності до безперервної самоосвіти, потреб у професійному зростанні, гнучкості соціальнопедагогічного мислення, гуманістичної спрямованості особистості. На нашу

Професіоналізм педагога: теоретичні й методичні аспекти. - Вип. 14 (Ч. 2). - Слов'янськ, 2021. 
думку, важливим для магістра 3 державного управління $\epsilon$ набуття відповідних професійних компетентностей в умовах інформатизації освітнього середовища, у якому навчання відбувається на засадах усебічного врахування їх індивідуальних потреб і можливостей, вимог сучасного суспільства (Бобрицька \& Процька, 2017).

Великі обсяги навчальної інформації спонукають до пошуку індивідуальних способів оволодіння новими видами діяльності, серед яких аналіз, добір, узагальнення інформації (Биков, 2009). Навчальна діяльність сучасних студентів значною мірою визначається їхньою власною активністю в опануванні IKT, спирається на осмислене набуття набору професійних компетентностей, які необхідні для успішної самореалізації в майбутній професійній діяльності (Бобрицька \& Процька, 2016; Бобрицька \& Процька, 2017).

Дослідження формування професійних компетентностей майбутнього магістра освітніх наук в умовах інформатизації освіти як педагогічної проблеми уможливило проаналізувати різні підходи до розкриття сутнісного змісту компетентностей студентів ЗВО, що створило наукове підгрунтя до визначення структури професійних компетентностей майбутнього магістра освітніх наук. Тому компонентами структури професійних компетентностей майбутнього магістра освітніх наук $є$ :

предметна (здатність самостійно набувати нові знання й уміння за фахом; здатність до розв'язування проблем у предметній галузі діяльності);

інформаційно-цифрова (володіння інформаційними технологіями; спроможність знаходити інформацію; здатність систематизувати, узагальнювати iii; здатність до критичного ставлення до інформації, поширюваної медійними засобами й рекламою; здатність застосовувати знання, виявляти інформаційну грамотність);

- комунікативна (володіння сукупністю вербальних і невербальних засобів комунікації; здатність вступати в комунікацію для порозуміння в ситуаціях професійного та міжособистісного спілкування);

особистісна (здатність до самостійної пізнавальної діяльності, що передбачає спроможності до постановки й розв'язання пізнавальних задач у навчальній та професійні галузі, пошук нестандартних рішень; створення та розв'язування проблемних ситуацій задля оптимізації процесів навчання й професійної діяльності; здатність навчатися впродовж життя; уміння аналізувати ситуацію на ринку праці тощо) (Бобрицька \& Процька, 2016; Бобрицька \& Процька, 2017; Bobrytska, Reva, Protska \& Chkhalo, 2020). 

С. ПРОЦЬКА
Використання сервісів Google під час вивчення курсу «Освітня політика»

Теоретично значущим для розв'язання завдань нашого дослідження $\epsilon$ висновки вчених, що нові соціальні сервіси спростили процес створення та публікації матеріалів у глобальній мережі Інтернет. Тепер кожен може не лише отримати доступ до світлин, відеофайлів, текстів, а й узяти участь у їх редагуванні та створенні власного мережного контенту. За допомоги сервісів Веб 2.0 контент створюється мільйонами людей. Вони розробляють і розміщують у мережі нові тексти, світлини, малюнки, музичні файли. Крім цього, спілкування між людьми все частіше відбувається не у формі прямого обміну відомостями, а у формі спостереження за діяльністю в мережі (Биков, 2009; Бобрицька \& Процька, 2016; Бобрицька \& Процька, 2017).

Зокрема, застосування Google сервісів у ЗВО може дати:

1) економію засобів на придбання програмового забезпечення;

2) зниження потреби в спеціалізованих аудиторіях, бо в будь-якій аудиторії можна організувати сучасний освітній процес, використовуючи ноутбуки й безпровідну мережу;

3) можливість виконання багатьох видів діяльності, контролю та оцінки досягнень студентів online;

4) відкритість освітнього середовища для тих, хто навчає (викладач), і тих, хто навчається (студент).

Крім того, засоби й технології інформаційно-комунікаційних мереж, зокрема й Інтернет, утворюють комп'ютерно орієнтовану платформу освітнього процесу вивчення навчальних дисциплін у вищій школі (Биков, 2009; Бобрицька \& Процька, 2016; Бобрицька \& Процька, 2019).

Успішний досвід розв'язання проблеми застосування магістрами освітніх наук Google сервісів у процесі фахової підготовки $є$ в Національному педагогічному університеті імені М.П. Драгоманова. Зокрема, у процесі вивчення навчальної дисципліни (освітнього компонента) «Освітня політика», під час проведення семінарських та практичних занять для студентів другого (магістерського) рівня вищої освіти освітньо-професійної програми 011 Освітні, педагогічні науки, викладач для залучення всієї цільової аудиторії та, крім цього, швидкого оцінювання підготовки всіх студентів, використовує різні сервіси Google. Далі докладніше розглянемо застосунок Google Classroom (Процька, 2017; Bobrytska \& Protska, 2018).

Починаючи з березня 2020 року в умовах карантину під час пандемії, спричиненої коронавірусом SARS-CoV-2, викладачі кафедри соціальної філософії, філософії освіти та освітньої політики факультету менеджменту освіти та науки НПУ імені М.П. Драгоманова активно використовували можливості застосунку Google Classroom для створення електронних навчальних

Професіоналізм педагога: теоретичні й методичні аспекти. - Вип. 14 (Ч. 2). - Слов'янськ, 2021. 
курсів дисциплін (рис. 1). Так як у всіх викладачів є корпоративна пошта Google, а студенти, маючи сучасні мобільні засоби зв'язку, також користуються поштами Google, застосунок Google Classroom є найдоступнішим.

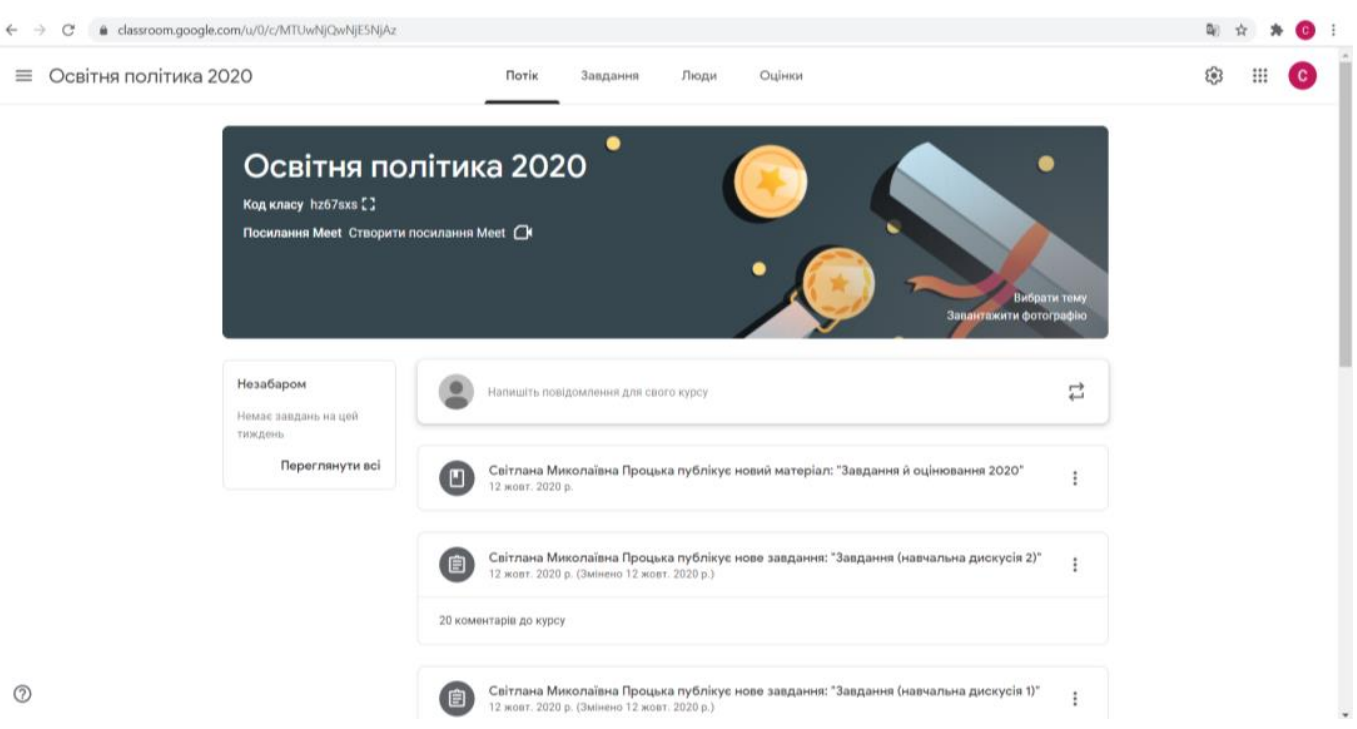

Рис. 1 Стартова сторінка електронного навчального курсу «Освітня політика» в Google Classroom

Так, у Google Classroom викладач у розділі «Завдання» відкрито розміщує всю необхідну інформацію зі своєї навчальної дисципліни (освітнього компоненту), яку вважає має засвоїти студент, опановуючи цей курс. Для прикладу, було взято електронний навчальний курс «Освітня політика» для студентів другого (магістерського) рівня вищої освіти (рис. 2). Курс містить два підрозділи: «Теоретичний матеріал», де викладач для студентів розмістив робочу програму та конспект лекцій, «Практичний матеріал», де містяться конкретні практичні завдання для виконання їх студентами.

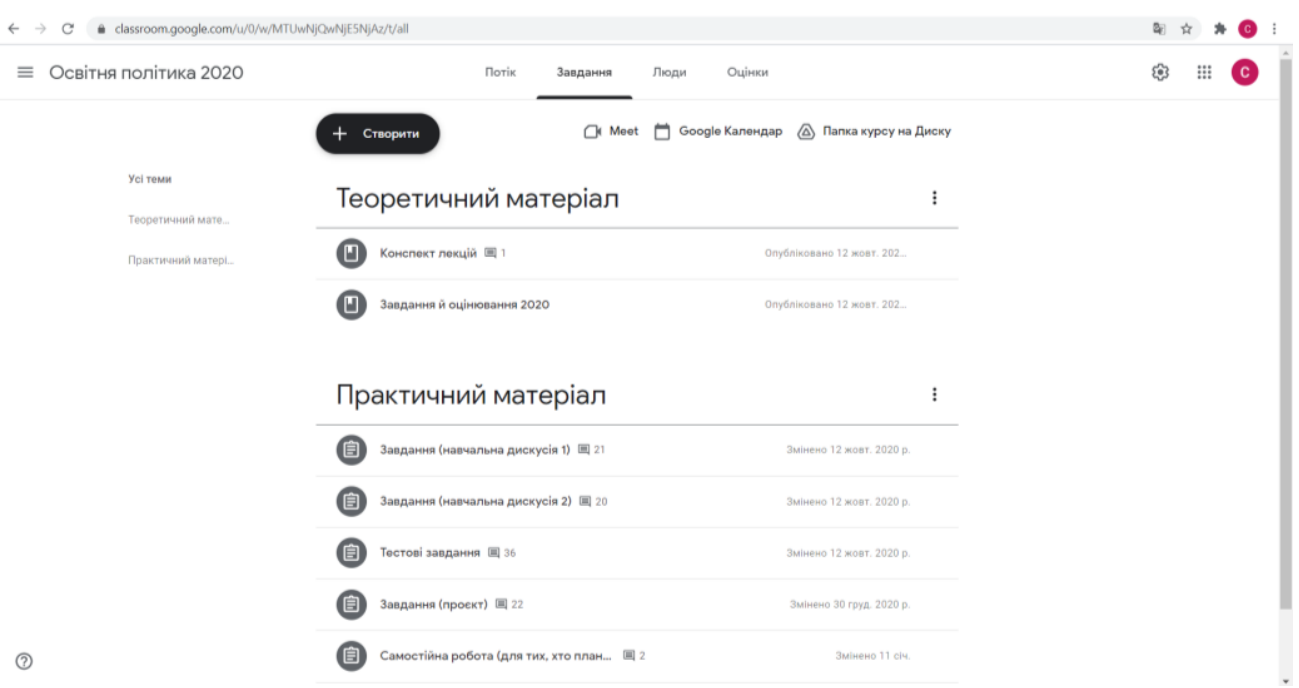

Рис. 2 Приклад розміщення матеріалів у Google Classroom 
У розділі «Люди» викладач має можливість залучати студентів до курсу, надіславши їм запрошення поштою чи покликання на цей курс через різні соціальні мережі, контролювати кількість зареєстрованих студентів, а також за необхідності вилучати їх (рис. 3).

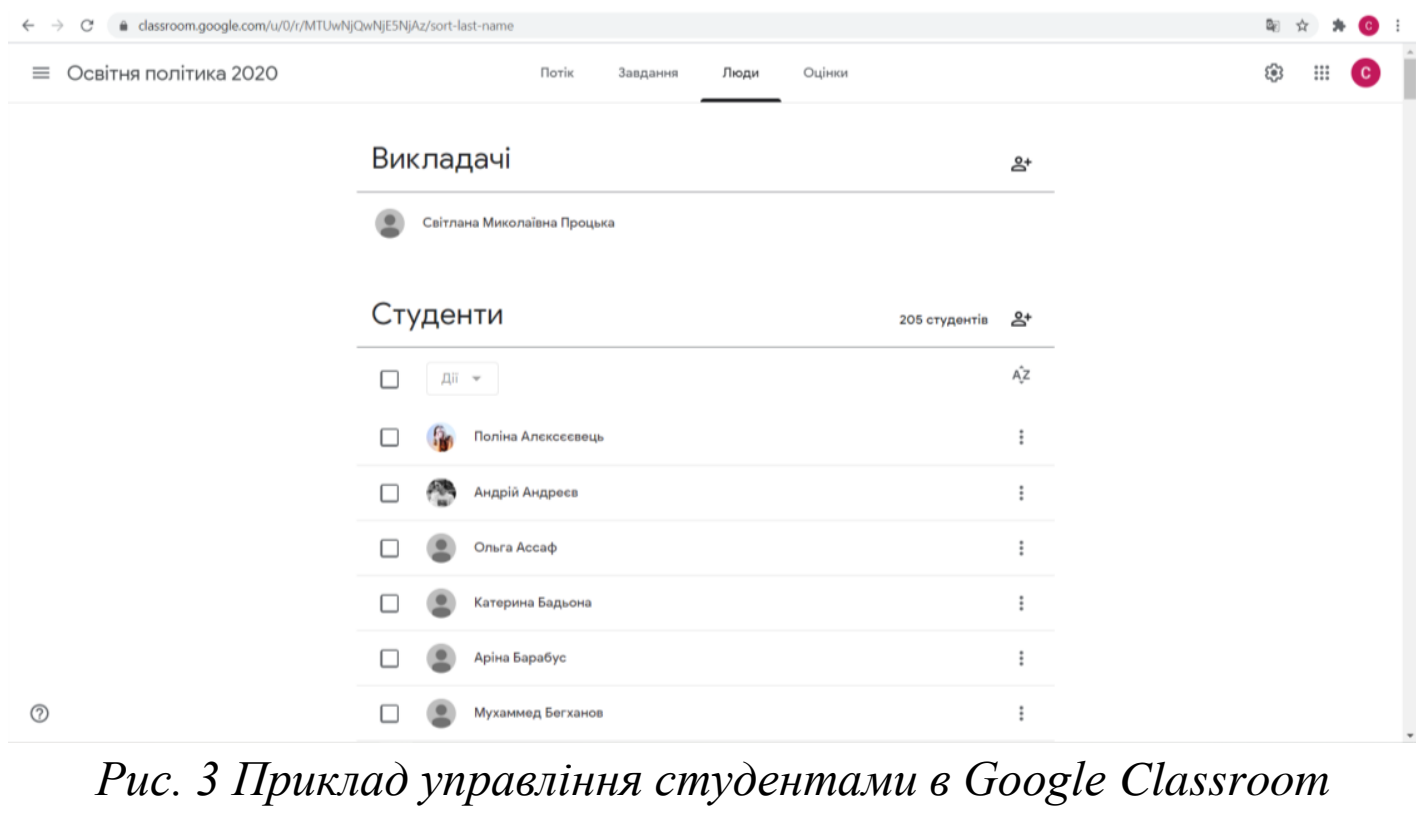

У розділі «Оцінки» викладач проводить оцінювання практичних завдань (рис. 4). Тут він легко й доступно, з економією власного часу на перевірку та зведенням даних по кожному студенту, швидко отримує загальну картину освітніх результатів студентів. За необхідності, викладач також може відвідати індивідуальну сторінку кожного студента та оцінити його окремо (рис. 5).

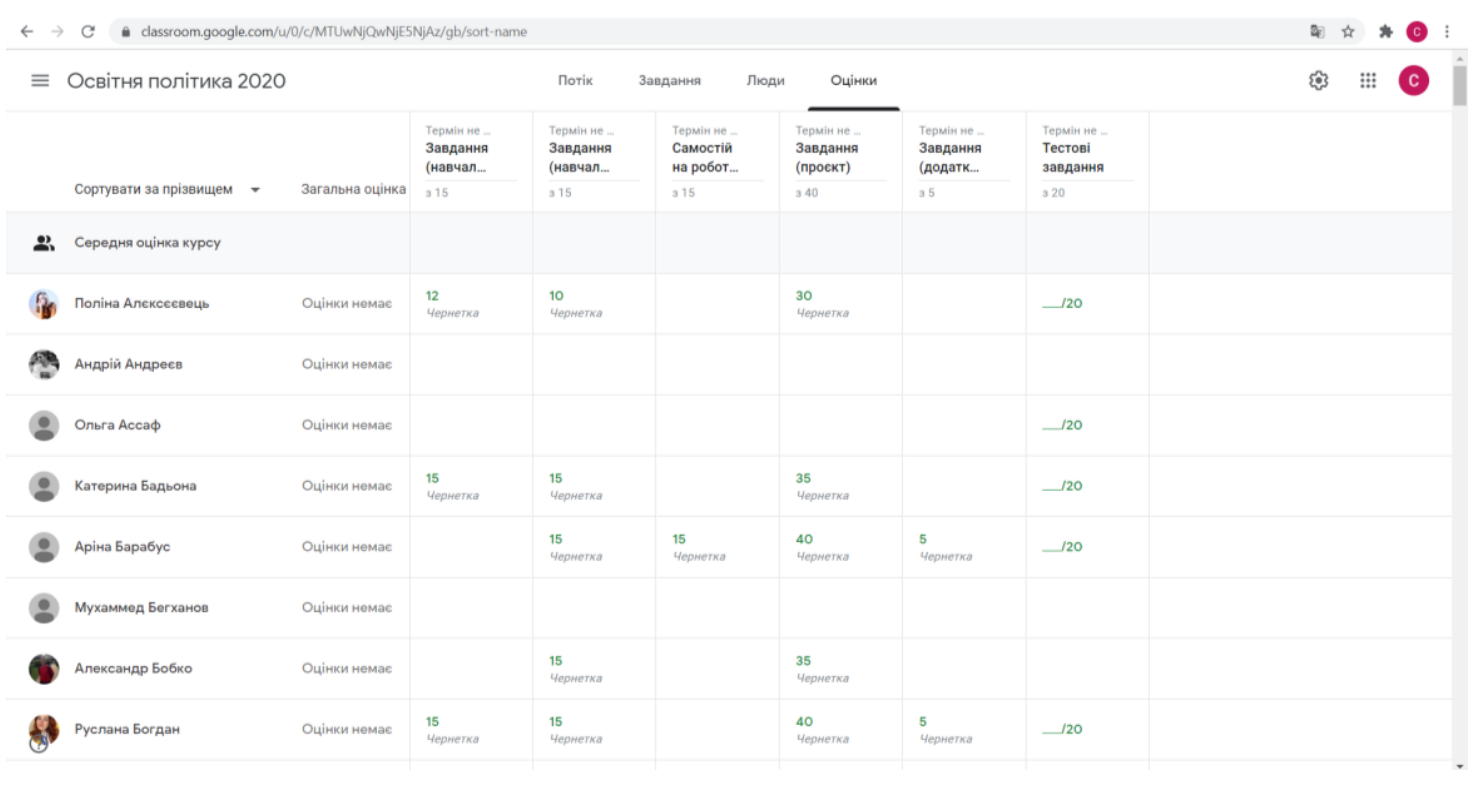

Рис. 4 Приклад оиінювання студентів у Google Classroom 
С. ПРОЦЬКА

Використання сервісів Google під час вивчення курсу «Освітня політика»

$\equiv$ Освітня політика 2020

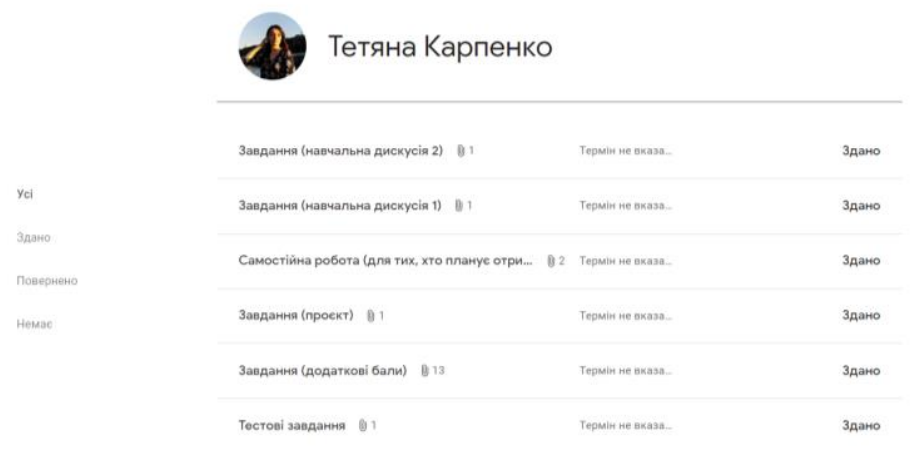

()

Рис. 5 Приклад сторінки студентки другого (магістерського) рівня вищої в Google Classroom

Зазначимо, що в розділі «Завдання» можна використовувати однин із доступних та ефективних сервісів Google як Google Forms. Так, викладач для залучення всієї цільової аудиторії й, крім цього, швидкого оцінювання підготовки всіх студентів із певного модуля чи теми може використовувати Google Forms (рис. 6, 7).

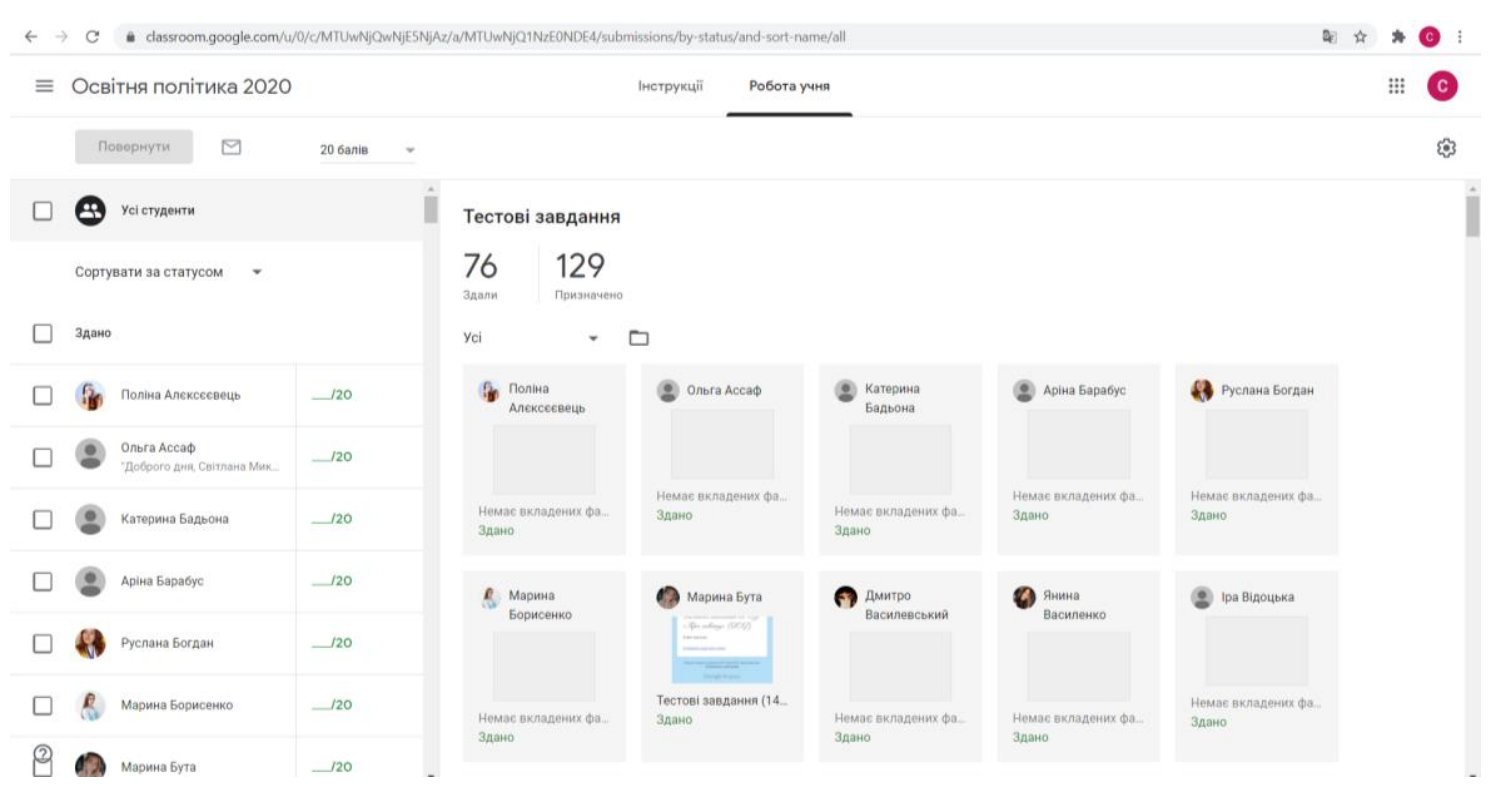

Рис. 6. Приклад вигляду завдання для студентів у Google Classroom 
С. ПРОЦЬКА

Використання сервісів Google під час вивчення курсу «Освітня політика»

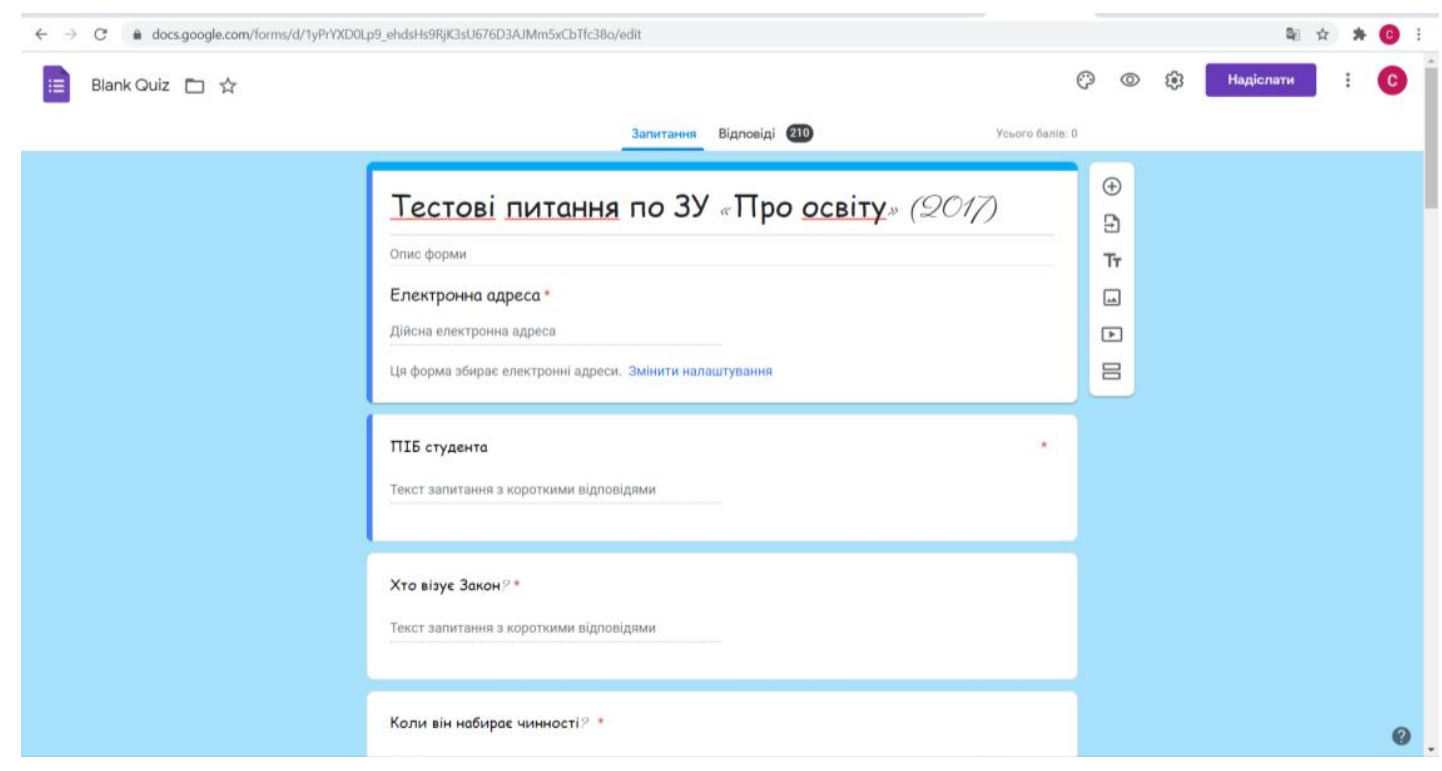

Рис. 7. Приклад Google Forms

Зважаючи на вищесказане, під час застосування сервісу Google студенти можуть ефективно засвоїти навчальний матеріал із відповідного курсу, що сприяє, на нашу думку, набуттю ними в освітньому процесі професійних компетентностей.

Висновки 3 дослідження і перспективи подальших розвідок у цьому напрямі. Враховуючи специфіку майбутньої професійної діяльності магістра освітніх наук, важливо зазначити, що застосування сервісів Google (наприклад, Google Classroom) створює для них на етапі набуття професії умови важливі для формування індивідуальних професійно орієнтованих мотивів, цінностей, набуття знань, умінь та досвіду, розвитку здібностей, творчих нахилів; надає новітні підходи до навчальної комунікації, співпраці та співробітництва. Отже, враховуючи результати наукової розвідки, вважаємо, що сервіси Google в процесі формування професійних компетентностей магістра освітніх наук в умовах інформатизації освіти відіграють вагому роль для сучасної системи вищої освіти. Перспективи подальших наукових розвідках убачаємо в розробленні педагогічних умов здійснення моніторингу результатів застосування сервісів Google в освітньому процесі закладів вищої освіти, зокрема й під час професійної підготовки магістра освітніх наук.

\section{СПИСОК ВИКОРИСТАНИХ ДЖЕРЕЛ}

1. Биков, В.Ю. (2009). Моделі організаиійних систем відкритої освіти. Київ: Атіка.

2. Бобрицька, В.I. (2011). Застосування інформаційно-комунікаційних технологій у вищій педагогічній освіті. Педагогічна освіта : теорія і практика. Педагогіка. Психологія, 16 (2), 35-39.

3. Бобрицька, В.І., Глушак О.М. (2014). Основи інформаційної культури бакалаврів $з$ філологіï. Полтава : Поліграфічний центр «Скайтек».

Професіоналізм педагога: теоретичні й методичні аспекти. - Вип. 14 (Ч. 2). - Слов’янськ, 2021. 


\title{
С. ПРОЦЬКА
}

Використання сервісів Google під час вивчення курсу «Освітня політика»

4. Бобрицька, В.I. (2015). Освітня політика України у сфері інформатизації освіти. Освітня політика: філософія, теорія, практика: монографія. За ред. В. П. Андрущенка. Київ: Вид-во НПУ імені М.П. Драгоманова, 273-316

5. Бобрицька, B.I., Процька, С.М. (2016). Комn'ютерно орієнтована освіта майбутніх філологів. Полтава: Скайтек.

6. Бобрицька, В.І., Процька, С.М. (2017). Формування професійних компетентностей майбутніх філологів засобами комп'ютерно орієнтованих технологій. Інформаційні технологї i засоби навчання, 2 (58), 59-66. doi: 10.33407/itlt.v58i2.1644

7. Бобрицька, B.I., Процька, C.M. (2019). Організаційно-педагогічні умови використання електронних навчальних курсів в освітньому процесі закладів вищої освіти України. Вісник Національного авіаиійного університету. Серія: Педагогіка. Психологія, 2 (15). 19-24. doi: 10.18372/2411-264x.15.14394

8. Процька, C.M. (2017). Мережні ІКТ як основа комп'ютерно орієнтованої методики формування професійних компетентностей майбутніх філологів. Педагогічна освіта: теорія $i$ практика. Психологія. Педагогіка, 27. 105-108.

9. Bobrytska, V.I., Protska, S.M. (2018). Formation of professional competencies of the future teachers by means of a computer-based methodology: investigational approach. Інформаційні технології і засоби навчання. 5 (67). 121-133. doi: 10.33407/itlt.v67i5.2307

10. Bobrytska, V.I., Reva, T.D., Protska, S.M. \& Chkhalo, O.M. (2020). Effectiveness and Stakeholders' Perceptions of the Integration of Automated E-Learning Courses into Vocational Education Programmes in Universities in Ukraine. International Journal of Learning, Teaching, and Educational Research, 19 (5), 27-46. doi: 10.26803/ijlter.19.5.3

\section{USE OF GOOGLE SERVICES DURING STUDY OF THE "EDUCATIONAL POLICY" COURSE}

\author{
Svitlana Protska \\ Candidate of Pedagogical Sciences, Associate Professor, \\ Associate Professor of the Department of Social Philosophy, Philosophy of \\ Education and Educational policy, \\ National Pedagogical Dragomanov University, \\ Kyiv, Ukraine \\ ORCID ID 0000-0002-9212-8700 \\ s.m.protska@npu.edu.ua
}

\begin{abstract}
Formation of professional competencies of the future specialist in the conditions of introduction of modern information technologies in practice of educational process is one of key priorities of development of pedagogical higher education of modern Ukraine. Thus, we consider a strategically important direction in the system of higher education, the organization and implementation of Google services in the educational environment, which create new opportunities for the realization of the personal potential of the future master of educational sciences.

Various aspects of the problem of improving the competence approach, the use of ICT in the training of future teachers are covered in the scientific works of domestic and foreign scientists, namely: investigated the theoretical and practical aspects of the use of ICT in the educational process - V. Bykov, O. Glazunova, O. Glushak, M. Zhaldak, O. Zhiltsov, Y. Zhuk, O. Kolgatin, K. Kolos, M. Leshchenko, S. Litvinova, A. Manako, N. Morse, Y. Nosenko, O. Ovcharuk, L. Petukhova, O. Pinchuk, O. Sokolyuk, N. Soroko, O. Spivakovsky, E. Spivakovskaya-Vandenberg, O. Spirin, Y. Trius, M. Shishkina, A. Yatsyshyn and others; substantiated the theoretical-methodological and methodological bases of application of the competence approach in the training of specialists with
\end{abstract}

(ㄷ ДВНЗ «Донбаський державний педагогічний університет» 


\section{С. ПРОЦЬКА}

Використання сервісів Google під час вивчення курсу «Освітня політика»

higher education - O. Antonova, N. Bibik, V. Bobrytska, L. Klos, L. Kravchenko, O. Lokshina, O. Ovcharuk, O. Pometun, O. Savchenko, V. Yagupov and others.

The purpose of the study is to substantiate the use of Google services during the study of the course "Educational Policy" for students of the second (master's) level of higher education in the context of informatization of pedagogical institutions of higher education.

The study of the formation of professional competencies of the future master of educational sciences in terms of informatization of education as a pedagogical problem allowed to analyze different approaches to disclosing the essential content of competencies of freelance students, which created a scientific basis for determining the structure of professional competencies of future master of educational sciences. Therefore, the components of the structure of professional competencies of the future master of educational sciences are: subject; information and digital; communicative; personal.

Successful experience in solving the problem of application of Google services by masters of educational sciences in their professional training is in the National Pedagogical Dragomanov University. In particular, in the process of studying the discipline (educational component) "Educational Policy", during seminars and practical classes for students of the second (master's) level of higher education educational and professional program 011 Educational, pedagogical sciences, teacher to attract the entire target audience and this quick assessment of the preparation of all students uses various Google services. Starting from March 2020 in the conditions of quarantine during the pandemic caused by the coronavirus SARS-CoV-2, teachers of the Department of Social Philosophy, Philosophy of Education and Educational Policy of the Faculty of Management of Education and Science of National Pedagogical Dragomanov University actively used the possibilities of using Google Classroom to create electronic training courses for disciplines.

Given the specifics of the future professional activity of the Master of Education, it is important to note that the use of Google services (e.g., Google Classroom) creates for them at the stage of acquiring a profession important for the formation of individual professional motives, values, knowledge, skills and abilities. creative inclinations; provides the latest approaches to educational communication, cooperation and collaboration.

Key words: master of educational sciences; informatization of education; information and communication technologies; professional competencies; Google Classroom service.

\section{REFERENCES}

1. Bykov, V.Yu. (2009). Models of organizational systems of open education. Kyiv: Attika.

2. Bobrytska, V.I. (2011). Application of information and communication technologies in higher pedagogical education. Pedagogical education: theory and practice. Pedagogy. Psychology, 16 (2), 35-39.

3. Bobrytska, V.I., Hlushak, O.M. (2014). Fundamentals of information culture of bachelors in philology. Poltava: Polihrafichnyi tsentr «Skaitek».

4. Bobrytska, V.I. (2015). Educational policy of Ukraine in the field of informatization of education. Educational policy: philosophy, theory, practice: monograph. Eds. V.P. Andrushchenko. Kyiv: Vyd-vo NPU imeni M.P. Drahomanova.

5. Bobrytska, V.I., Protska, S.M. (2016). Computer-oriented education of future philologists. Poltava: Skaitek.

6. Bobrytska, V.I., Protska, S.M. (2017). Formation of professional competencies of future philologists by means of computer-oriented technologies. Information Technologies and Learning Tools, 2 (58), 59-66. doi: 10.33407/itlt.v58i2.1644

7. Bobrytska, V.I., Protska, S.M. (2019). Organizational and pedagogical conditions for the use of electronic training courses in the educational process of higher education institutions of Ukraine. Bulletin of the National Aviation University. Series: Pedagogy. Psychology, 2 (15), 19-24. doi: 10.18372/2411-264x.15.14394

Професіоналізм педагога: теоретичні й методичні аспекти. - Вип. 14 (Ч. 2). - Слов'янськ, 2021. 
8. Protska, S.M. (2017). Network ICT as a basis of computer-oriented methods of forming professional competencies of future philologists. Pedagogical education: theory and practice. Psychology. Pedagogy, 27, 105-108.

9. Bobrytska, V.I., Protska, S.M. (2018). Formation of professional competencies of the future teachers by means of a computer-based methodology: investigational approach. Information Technologies and Learning Tools, 5 (67), 121-133. doi: 10.33407/itlt.v67i5.2307

10. Bobrytska, V.I., Reva, T.D., Protska, S.M. \& Chkhalo, O.M. (2020). Effectiveness and Stakeholders' Perceptions of the Integration of Automated E-Learning Courses into Vocational Education Programmes in Universities in Ukraine. International Journal of Learning, Teaching, and Educational Research, 19 (5), 27-46. doi: 10.26803/ijlter.19.5.3

Матеріали надійшли до редакції 16.04.2021 р. 